\title{
EGFR Exon 19 Insertion Mutation
}

National Cancer Institute

\section{Source}

National Cancer Institute. EGFR Exon 19 Insertion Mutation. NCI Thesaurus. Code C134465.

A molecular genetic abnormality indicating the presence of an in-frame insertion mutation occurring within exon 19 of the EGFR gene. 